ISSN : $2302-1590$

E-ISSN : $2460-190 X$

ECONOMICA

Journal of Economic and Economic Education Vol.3 No.1 (1-17)

\title{
PERAN BANK PEMBIAYAAN RAKYAT SYARIAH DALAM PENGEMBANGAN UMKM DAN AGRIBISNIS PEDESAAN DI SUMATERA BARAT
}

\author{
Sri Maryati \\ Mahasiswa Prog S3 Ilmu Ekonomi FE Universitas Andalas \\ Staf Pengajar Jurusan IE-FE Universitas Andalas \\ Kampus Unand Limau Manis Padang \\ email: srie_jayamahe@yahoo.co.id
}

submited: 2014.05.15 reviewed:2014.07.30 accepted: 2014.10.30

http://dx.doi.org/10.22202/economica.2014.v3.i1.231

\begin{abstract}
Micro, Small and Medium Enterprises (SMEs) is one component of businesses that have a large contribution in creating jobs in Indonesia. Therefore, the existence of Micro, Small and Medium Enterprises ( SMEs ) is very important people who have limited economic resources and skills. This business is a means to earn a living, and develop potential or skills they possess. One type of business that SMEs have an important role in the economy of the community in West Sumatra is agribusiness. This business was instrumental in encouraging the agricultural sector, which has the largest contribution with the average contribution of $23.81 \%$ of GDP over the period 2018-2012. Agribusiness development must also be able to boost farmers' income. In conducting its business SMEs often experience difficulties and obstacles, including the issue of marketing, capital, and management. Approximately 57\% of micro and small businesses in Indonesia have difficulty in carrying out its business, the main difficulty encountered is the difficulty of capital that is equal to $31.11 \%$, raw material difficulties of $24.80 \%$, and $24.60 \%$ of the marketing difficulties (Central Bureau of Statistics,2010) One of the sources of financing that can assist SMEs in overcoming the problem of capital is BPRS. This study aims to analyze the role of BPRS in the development of SMEs in general and rural agribusiness, especially in West Sumatra
\end{abstract}

\begin{abstract}
Abstrak
Usaha Mikro Kecil Menengah (UMKM) merupakan salah satu komponen pelaku usaha yang mempunyai sumbangan cukup besar dalam menciptakan lapangan pekerjaan di Indonesia. Oleh sebab itu keberadaan Usaha Mikro Kecil Menengah (UMKM) sangat dibutuhkan masyarakat khususnya masyarakat dengan kemampuan ekonomi dan keterampilan yang terbatas sebagai sarana untuk mendapatkan penghasilan, dan mengembangkan potensi atau keterampilan yang mereka miliki. Salah satu jenis usaha UMKM yang memiliki peran penting dalam perekonomian masyarakat di Sumatera Barat adalah agribisnis karena di daerah ini sector pertanian mempunyai kontribusi terbesar dengan rata-rata kontribusi $23,81 \%$ dari PDRB selama periode tahun 2018-2012. Perkembangan agribisnis tentunya juga akan dapat mendorong peningkatan pendapatan petani. Dalam menjalankan usahanya seringkali UMKM mengalami berbagai kesulitan dan hambatan, diantaranya adalah masalah pemasaran, permodalan, dan pengelolaan. Sekitar $57 \%$ usaha mikro dan kecil di Indonesia mengalami kesulitan dalam menjalankan usahanya, dengan kesulitan utama yang dihadapi adalah kesulitan permodalan yaitu sebesar 31,11\%, kesulitan bahan baku sebesar 24,80\%, dan kesulitan pemasaran sebesar 24,60\% (BPS Indonesia, 2010). Salah satu sumber pembiayaan yang dapat membantu UMKM dalam mengatasi masalah permodalan adalah BPRS. Kajian ini bertujuan untuk menganalisa peran BPRS dalam pengembangan usaha UMKM pada umumnya dan agribisnis pedesaan khususnya di wilayah Sumatera Barat
\end{abstract}

Keywords : SMEs, Agribusiness, finance, business development and BPRS

C2014 Prodi Pendidikan Ekonomi STKIP PGRI, Padang 


\section{PENDAHULUAN}

Usaha Mikro Kecil Menengah (UMKM) merupakan salah satu komponen pelaku usaha yang mempunyai sumbangan cukup besar dalam menciptakan lapangan pekerjaan di Indonesia (BPS Indonesia, 2010). Oleh sebab itu keberadaan Usaha Mikro Kecil Menengah (UMKM) sangat dibutuhkan masyarakat khususnya masyarakat dengan kemampuan ekonomi dan keterampilan yang terbatas. Peranan penting UMKM dalam kehidupan masyarakat adalah sebagai tempat mendapatkan penghasilan, dan mengembangkan potensi atau keterampilan yang mereka miliki.

Sektor UMKM juga memberikan kontribusi yang sangat penting bagi perekonomian Indonesia pada masa krisis, dimana UMKM memiliki daya tahan meghadapi krisis ekonomi yang terjadi karena UMKM tidak banyak memiliki ketergantungan pada faktor eksternal seperti hutang dalam valuta asing, dan bahan baku impor dalam melakukan kegiatan operasionalnya (Malik, 2008).

Keunggulan sektor UMKM tersebut menjadi kekuatan bagi UMKM dalam mempertahankan usahanya pada saat perekonomian nasional dilanda krisis. Minimnya ketergantungan UMKM terhadap hutang pada pihak asing dan bahan baku impor, membuktikan bahwa sektor UMKM memiliki kepercayaan diri yang cukup besar dalam membiayai dan mengelola usahanya sendiri tanpa melibatkan campur tangan pihak asing. Maka, dalam hal ini UMKM mengandalkan semua aspek permodalan dan bahan baku domestik (dalam negeri), sehingga mencerminkan suatu usaha yang mampu mengoptimalkan penggunaan sumber daya nasional.

Dalam menjalankan usahanya seringkali UMKM mengalami berbagai kesulitan dan hambatan, dimana dalam pengembangan usahanya UMKM seringkali menghadapi masalah yang mencakup masalah pemasaran, permodalan, dan pengelolaan. Sekitar 57\% usaha mikro dan kecil di Indonesia mengalami kesulitan dalam menjalankan usahanya, dengan kesulitan utama yang dihadapi adalah kesulitan permodalan yaitu sebesar $31,11 \%$, kesulitan bahan baku sebesar 24,80\%, dan kesulitan pemasaran sebesar $24,60 \%$ (BPS Indonesia, 2010).

Dengan kebijakan Pakto 1988, BPR tumbuh dan berkembang di Indonesia, hal ini telah membuka peluang baru bagi masyarakat kecil khususnya di kawasan pedesaan untuk memperoleh modal usaha. Selain itu, kehadiran BPR juga membantu masyarakat yang menginginkan modal atau pembiayaan dalam jumlah yang kecil, karena pembiayaan yang diberikan oleh BPR adalah pembiayaan yang difokuskan pada pembiayaan kecil dan mikro.

Akan tetapi sistem pembiayaan konvensional yang menerapkan sistem bunga seringkali mengakibatkan UMKM menghadapi kesulitan dalam mendapatkan pembiayaan usaha. Kecenderungan peningkatan suku bunga bank menyebabkan pelaku usaha UMKM khususnya dan masyarakat yang memiliki keterbatasan kemampuan ekonomi tidak mampu lagi melunasi hutang-hutangnya pada pihak bank, dan akhirnya pihak bank akan menyita harta benda mereka untuk melunasi hutang-hutangnya, karena 
pihak bank tentunya juga tidak akan mau dirugikan.

Untuk itu, masyarakat dan pelaku usaha berskala ekonomi mikro dan kecil membutuhkan sistem pembiayaan yang lebih mendukung pada keberhasilan usaha yaitu dengan sistem bagi hasil. Jenis transaksi seperti ini dapat dilakukan oleh perbankan syariah yang merupakan lembaga keuangan dengan prinsip operasional yang

Tabel 1.

Pembiayaan Bank Pembiayaan Rakyat Syariah (BPRS) berdasarkan

Golongan Pembiayaan Tahun 2008-2014 (Rp Juta)

\begin{tabular}{|c|c|c|c|c|c|c|c|c|}
\hline $\begin{array}{l}\text { GOLONGAN } \\
\text { PEMBIAYAAN }\end{array}$ & 2008 & 2009 & 2010 & 2011 & 2012 & 2013 & 2014* & $\underset{(\%)}{\mathbf{g}}$ \\
\hline $\begin{array}{l}\text { Usaha Kecil dan } \\
\text { Menengah }\end{array}$ & 657,359 & 833,076 & $1,115,962$ & $1,547,205$ & $2,080,094$ & $2,620,263$ & $2,579,797$ & 31,87 \\
\hline $\begin{array}{l}\text { Porsi dari Total } \\
\text { Pembiayaan }(\%)\end{array}$ & 52.31 & 52.50 & 54.16 & 57.82 & 58.54 & 59.10 & 58.33 & 2,47 \\
\hline $\begin{array}{l}\text { Selain Usaha } \\
\text { Kecil dan } \\
\text { Menengah }\end{array}$ & 599,291 & 753,843 & 944,475 & $1,128,725$ & $1,473,426$ & $1,813,230$ & $1,842,877$ & 24,79 \\
\hline $\begin{array}{l}\text { Porsi dari Total } \\
\text { Pembiayaan }(\%)\end{array}$ & 47.69 & 47.50 & 45.84 & 42.18 & 41.46 & 40.90 & 41.67 & $-3,03$ \\
\hline Total & $1,256,650$ & $1,586,919$ & $2,060,437$ & $2,675,930$ & $3,553,520$ & $4,433,492$ & $4,422,674$ & 28,67 \\
\hline
\end{tabular}

Sumber: Statistik Perbankan Syariah, 2014

Catatan : *: data sampai Januari 2014

$\mathrm{g}=$ Pertumbuhan Rata-rata tahun 2008-2013 (\%)

Dari tabel di atas tampak bahwa selama periode 2008-2014 telah terjadi kenaikan jumlah pembiayaan yang diberikan oleh BPRS terhadap sektor usaha kecil dan menengah, dimana pertumbuhan rata-rata pembiayaan untuk UMKM selama periode tahun 2008-2010 adalah $31,87 \%$ dan untuk pembiayaan selain UMKN bertumbuh dengan $24,75 \%$. Dari sisi porsi pembiayaan, UMKM mendapatkan pembiayaan yang lebih besar dibandingkan selain UMKM. Hal ini menunjukkan bahwa BPRS didasarkan pada konsep syariah Islam, yang mengharamkan adanya bunga (riba), dan menerapkan sistem bagi hasil (profit loss sharing) pada setiap transaksinya (Antonio, 2001).

$$
\text { Peran BPRS (Bank }
$$

Pembiayaan Rakyat Syariah ) dalam memberikan pembiayaan berdasarkan golongan pembiayaan pada sektor ekonomi di Indonesia, dapat dilihat pada tabel di bawah ini. 
Kondisi terburuk dialami oleh UMKM pada saat terjadinya gempa yang mengguncang Sumatera Barat pada bulan September tahun 2009. Peristiwa tersebut telah menghancurkan sendi-sendi perekonomian daerah, Kamar Dagang dan Industri (Kadin) Indonesia memperkirakan sebanyak 80\% UMKM menderita kerugian miliaran rupiah (Ekonomi Neraca, 2010).

Meskipun pada tahun 2010 telah terjadi pemulihan ekonomi , namun menurut Bank Indonesia aktivitas ekonomi pada 2010 tersebut lebih banyak didorong oleh dana bantuan yang terus mengalir ke Sumatera Barat, pada kondisi riilnya aktivitas ekonomi di Sumatera Barat memang sangat lambat bahkan cenderung mundur atau tidak bergerak sebagai akibat dari terjadinya bencana gempa bumi dan tsunami. Untuk memacu pertumbuhan ekonomi daerah ini lebih cepat, maka upaya pertama yang harus dilakukan adalah memaksimalkan pemberdayaan UMKM. (Haluan, Senin, 06 Oktober 2014).

Melihat kondisi UMKM yang masih dihadapkan pada banyak permasalahan, ditambah lagi dengan terjadinya gempa yang menyebabkan UMKM semakin sulit untuk mengembangkan usahanya. Terutama sebagai masyarakat muslim yang menginginkan transaksi yang halal tanpa bunga dan sesuai dengan syariah agama Islam, pilihan pembiayaan yang tepat adalah dengan menggunakan pembiayaan produktif melalui instrumen perbankan syariah yaitu Bank Pembiayaan Rakyat Syariah (BPRS).
Studi ini mengkaji tentang bagaimana peran Bank Pembiayaan Rakyat Syariah (BPRS) dalam pengembangan Usaha Mikro Kecil Menengah (UMKM) di Sumatera Barat dengan menganalisis kajian yang pernah dilakukan di wilayah Sumatera Barat. Selanjutnya, penelitian ini diharapkan akan dapat memberikan manfaat bagi pihak terkait yaitu pemerintah daerah, BPRS dan para pengamat topik terkait sebagai suatu masukan dalam menetapkan kebijakan mengenai penerapan pembiayaan berbasis syariah untuk meningkatkan pertumbuhan Usaha Mikro Kecil Menengah, dan sumbangan wawasan pemikiran secara akademis guna meningkatkan kajian sejenis di masa mendatang.

\section{METODE PENELITIAN}

Kajian ini menggunakan metode analisa deskriptif-kualitatif berbasis kajian kepustakaan (library research). Analisa deskriptif kualitatif merupakan analisis yang didasarkan pada pemetaan permasalahan yang terdapat dalam dua variabel

kasus yang kemudian dicari titik korelasinya. Korelasi tersebut bisa dalam bentuk mengkonfirmasi, menolak, dan sependapat berdasarkan pada pengumpulan data yang dilakukan oleh peneliti. Sedangkan studi kepustakaan merupakan instrument penelitian dengan mengumpulkan berbagai macam literatur baik dalam bentuk jurnal, buku, prosiding, working paper, maupun sumber data lainnya yang memiliki keterkaitan dengan permasalahan dalam kajian ini.

Memberikan pembiayaan 
UMKM merupakan skala usaha yang paling besar jumlahnya di Indonesia, berdasrkan jumlah tenaga kerja yang digunakan dalam menjalankan usaha BPS Indonesia (2009) mengemukakan pengertian usaha mikro, kecil, dan menengah sebagaiman dapat dilihat pada tabel dibawah ini.

\section{Tabel 2 . Kriteria Usaha Mikro, Kecil, dan Menengah berdasarkan Jumlah} Tenaga Kerja Menurut Badan Pusat Statistik Indonesia

\begin{tabular}{ccc}
\hline No. & Klasifikasi Skala Usaha & Jumlah Tenaga Kerja \\
\hline 1. & Usaha Mikro & $1-4$ orang \\
2. & Usaha Kecil & $5-19$ orang \\
3. & Usaha Menengah & $20-99$ orang
\end{tabular}

Sumber: Statistik Indonesia, 2009

Berdasarkan asset yang dimiliki dan penjualan, maka Kementrian Negara Koperasi dan Usaha Kecil \& Menengah (2008), mengemukakan pengertian usaha mikro, usaha kecil, dan usaha menengah adalah sebagai berikut:

1) Usaha mikro adalah usaha produktif milik orang perorangan dan/atau badan usaha perorangan. Memiliki kekayaan bersih paling banyak Rp. 50 juta tidak termasuk tanah dan memiliki hasil penjualan tahunan paling banyak Rp. 300juta.

2) Usaha kecil adalah usaha ekonomi produktif yang berdiri sendiri, yang dilakukan oleh perorangan atau badan usaha yang bukan merupakan anak perusahaan atau bukan cabang perusahaan yang dimiliki, dikuasai, atau menjadi bagian baik langsung maupun tidak langsung dari usaha menengah atau usaha besar. Memiliki kekayaan bersih lebih dari Rp 50 juta sampai dengan paling banyak Rp. 500 juta tidak termasuk tanah dan bangunan atau memiliki hasil penjualan tahunan lebih dari Rp. 300 juta sampai dengan paling banyak Rp. 2,5 miliar.

3) Usaha menengah adalah usaha ekonomi produktif yang berdiri sendiri, yang dilakukan oleh orang perseorangan atau badan usaha yang bukan merupakan anak perusahaan atau cabang perusahaan yang dimiliki, dikuasai, atau menjadi bagian baik langsung maupun tidak langsung dengan usaha kecil atau usaha besar dengan jumlah kekayaan bersih atau hasil penjualan tahunan. Memiliki kekayaan bersih lebih dari Rp. 500 juta sampai dengan paling banyak Rp. 10 miliar tidak termasuk tanah dan bangunan atau memiliki hasil penjualan tahunan lebih dari Rp. 2,5 miliar sampai dengan paling banyak Rp. 50 miliar.

Ada dua pandangan yang mencoba menjelaskan tentang penyebab sulit berkembangnya UMKM di Indonesia yaitu: (Zahro,2010)

1) Pandangan Kultural, menurut pemikiran kelompok ini Usaha kecil (ekonomi rakyat) kurang berkembang karena adanya nilai -nilai atau tradisi suatu 
kelompok masyarakat yang memang tidak mampu mendinamisasi keadaan masyarakat. Hal ini yang menyebabkan UMKM tidak bisa berkembang dan kurang diminati oleh masyarakat. Banyak UMKM yang hidup di bawah rata-rata bahkan hidup dalam kemiskinan karena tidak sanggup beradaptasi dengan masyarakat. Sifat malas dan tidak memiliki etos kerja menyebabkan timbulnya kemiskinan yang tinggi, karena dengan menganggur tidak akan memperoleh pendapatan, sehingga kemiskinan semakin banyak. Solusi yang bisa ditawarkan adalah perlu adanya suatu usaha yang dapat membangkitkan semangat orang-orang seperti ini agar mau bekerja, diantaranya dengan terciptanya lapangan kerja yang mampu menampung sesuai dengan keterampilan yang mereka miliki dan upah yang memadai, sehingga bisa memenuhi kebutuhannya.

2) Pendekatan Struktural, menurut pandangan ini UMKM sulit berkembang disebabkan oleh sruktur sosial-ekonomi masyarakat yang timpang, yang menyebabkan adanya sekelompok tertentu yang sulit bahkan UMKM tidak bisa mengembangkan usahanya. Karena pengaruh struktur perekonomian Indonesia yang belum jelas dan terjadi resesi yang benyebabkan banyaknya pengangguran sebagai akibat terjadinya kenaikan biaya produksi sedangkan selera pasar menurun karena terjadinya inflasi,maka perusahaan banyak yang melakukan PHK. Untuk mengatasi masalah prekonomian yang seperti ini perlu dilakukan penataan dan penguatan struktur sosial-ekonomi masyarakat secara signifikan. Termasuk dalam struktur sosial-ekonomi adalah permasalahan yang berhubungan dengan pelaku ekonomi, kekuasaan, dan kondisi politik

\section{PEMBAHASAN}

Temuan Empiris: Peran BPRS dalam Pengembangan UMKM di Sumatera Barat

\section{1) Gambaran Umum wilayah dan Potensi Ekonomi Sumatera Barat}

Gambaran umum perekonomian Sumatera Barat dapat dilihat pada table di bawah ini. 
Tabel 3. Konstribusi Lapangan Usaha pada PDRB Atas Dasar HargaBerlaku (ADHB) Provinsi Sumatera Barat Tahun 2008 s/d 2012 (\%)

\begin{tabular}{|c|c|c|c|c|c|c|c|}
\hline No & Lapangan Usaha & 2008 & 2009 & 2010 & 2011* & $2012 * *$ & Rata-rata \\
\hline 1 & Pertanian & 24.49 & 23.95 & 23.94 & 23.66 & 23.01 & 23.81 \\
\hline 2 & Pertambangan \& Penggaliaan & 3.32 & 3.33 & 3.17 & 2.97 & 2.9 & 3.14 \\
\hline 3 & Industri Pengolahan & 12.12 & 12.09 & 11.69 & 11.39 & 11.15 & 11.69 \\
\hline 4 & Listrik, gas \& air bersih & 1.22 & 1.17 & 1.06 & 0.98 & 0.95 & 1.08 \\
\hline 5 & Bangunan & 5.56 & 5.63 & 6.3 & 6.58 & 6.68 & 6.15 \\
\hline 6 & Perdagangan, hotel \& restoran & 17.66 & 17.84 & 17.74 & 18.02 & 18.45 & 17.94 \\
\hline 7 & Pengangkutan dan Komunikasi & 15.06 & 15.21 & 15.38 & 15.62 & 15.89 & 15.43 \\
\hline \multirow[t]{2}{*}{8} & Keuangan, Persewaan \& Jasa & & & & & & \\
\hline & Perusahaan & 4.88 & 4.93 & 4.74 & 4.52 & 4.52 & 4.72 \\
\hline 9 & Jasa-jasa & 15.69 & 15.86 & 15.97 & 16.26 & 16.45 & 16.05 \\
\hline \multicolumn{2}{|c|}{ Total PDRB } & 100.00 & 100.00 & 100.00 & 100.00 & 100.00 & 100.00 \\
\hline
\end{tabular}

Sumber: BPS Sumbar, 2013.

Dari tabel 3 dapat dilihat bahwa kontributor terbesar dalam perekonomian Sumatera Barat adalah sector pertanian, yang didukung oleh sector perdagangan, pengangkutan, hotel \& restoran, sektor pengangkutan dan komunikasi serta jasa-jasa. Dengan pertumbuhan ratarata $6 \%$ selama peride waktu 2008 2012, sedangkan pertumbuhan sektor pertanian untuk periode yang sama adalah $4,18 \%$. Angka pertumbuhan ini termasuk yang rendah dibandingkan dengan lapangan usaha lainnya. Adapun lapangan usaha yang memiliki pertumbuhan tertinggi adalah lapangan usaha pengangkutan dan komunikasi yakni sebesar $8,63 \%$.

2) Kajian Peran PT. Bank Pembiayaan Rakyat Syariah

\section{Ampek Angkek Candung dalam Pengembangan UMKM Kabupaten Agam}

PT. Bank Pembiayaan Rakyat Syariah (BPRS) Ampek Angkek Candung hadir sejak tahun 1999. Hal ini merupakan hikmah sekaligus berkah pasca krisis ekonomi dan moneter tahun 1997-1998. Sebagaimana diketahui, krisis ekonomi dan moneter sejak Juli 1997 telah menimbulkan beragam dampak negatif yang sangat hebat terhadap sendi kehidupan masyarakat, tidak terkecuali dunia usaha. Dalam kondisi tersebut, industri perbankan nasional yang didominasi oleh bankbank konvensional mengalami krisis.

Diawali dengan tujuan untuk mengurangi ruang gerak para 
rentenir yang berada di daerah Kecamatan Ampek Angkek dan Candung, maka para perantau masyarakat Ampek Angkek Candung di Jakarta dan Bandung bertekad untuk mendirikan satu BPR sebagai tulang punggung ekonomi masyarakat setempat. Berkat kerja keras dari para pendiri sejak tahun 1996, akhirnya Bank Indonesia mengeluarkan Surat Izin Usaha dengan No. SK 32/57/KE/Dir tanggal 14 Mei 1999 sebagai bank yang beroperasi berdasarkan prinsip Syariah dengan nama PT. BPR Syariah Ampek Angkek Candung sebagaimana tercantum dalam Akta Notaris H. Sofyan, SH No. 1 tanggal 2 Februari 1998. PT BPR Syariah Ampek Angkek Candung secara resmi mulai beroperasi sejak tanggal 12 Juli 1999.

Karakteristik nasabah pembiayaan UMKM dari PT. BPRS Ampek Angkek Candung dilihat dari jenis kelamin, tingkat umur, satus perkawinan, tingkat pendidikan, dan lamanya pengalaman mengelola usaha. Dari hasil analisis terhadap nasabah pembiayaan PT. BPRS Ampek Angkek Candung ditemukan bahwa:
a) Nasabah pembiayaan berjenis $55,33 \%$ dan sebesar $44,67 \%$ berjenis kelamin perempuan.
b) Nasabah pembiayaan UMKM dari PT. BPRS Ampek Angkek Candung paling banyak berumur antara 41-50 tahun, yaitu $42,72 \%$, dan kemudian $31,07 \%$ nasabah pembiayaan UMKM berusia antara 31-40 tahun, dan yang paling sedikit adalah responden nasabah pembiayaan yang berusia $>60$ tahun yaitu

sebesar 3,88\% dari keseluruhan nasabah pembiayaan.

c) Berdasarkan status perkawinan, ditemukan bahwa sebesar 90,29\% responden nasabah pembiayaan berstatus sudah menikah, 6,79\% nasabah pembiayaan berstatus belum menikah, dan sebesar 2,92\% responden nasabah pembiayaan berstatus duda atau janda.

d) Berdasarkan tingkat pendidikan, hasil studi menemukan bahwa sebagian besar tingkat pendidikan nasabah pembiayaan UMKM dari PT. BPRS Ampek Angkek Candung adalah berpendidikan SLTA, yakni sebesar $57,28 \%$, sedangkan yang berpendidikan SLTP adalah sebesar 28,16\%, kemudian, sebesar $5,83 \%$ responden nasabah pembiayaan berpendidikan SD, dan sebesar $4,85 \%$ nasabah pembiayaan berpendidikan sarjana, serta berpendidikan diploma sebesar $3,88 \%$.

e) Dari lamanya pengalaman mengelola usaha ditemukan bahwa sebagian besar nasabah pembiayaan UMKM dari PT. BPRS Ampek Angkek Candung memiliki pengalaman mengelola usaha antara 1 sampai 5 tahun, yakni sebesar 50,46\%. Sedangkan yang memiliki pengalaman dalam mengelola usaha selama 5 - 10 tahun adalah sebesar 40,78\%. Selanjutnya, sebesar $\quad 4,86 \%$ nasabah pembiayaan memiliki pengalaman mengelola usaha selama 10 - 15 tahun, dan yang sebesar $0,9 \%$ baru mengelola usaha selama kurang dari 1 tahun. 
Selanjutnya untuk melihat karakterisktik usaha nasabah pembiayaan UMKM dari PT. BPRS Ampek Angkek Candung, dilihat dari faktor jenis usaha, status tempat usaha, status kepemilikan usaha, dan status hukum usaha. Dengan hasil analisis sebagai berikut:

a) Sebagian besar jenis usaha nasabah pembiayaan UMKM dari PT. BPRS Ampek Angkek Candung adalah usaha perdagangan, yakni sebesar $49,51 \%$, sebesar 20,39\% memiliki usaha dibidang jasa. Selanjutnya, sebesar $18,45 \%$ memiliki usaha dibidang kerajinan rumah tangga, dan yang memiliki usaha di bidang pertanian $9,71 \%$ dan perikanan sebesar $1.94 \%$ dari keseluruhan nasabah.

b) Berdasarkan status tempat usaha ditemukan bahwa sebagian besar nasabah pembiayaan bank ini telah memiliki tempat usaha sendiri, yakni sebesar $85,44 \%$ dan sebesar $14,56 \%$ lainnya mempunyai tempat usaha yang disewa.

c) Dari status kepemilikan usaha menunjukkan bahwa mayoritas merupakan milik sendiri yakni sebesar 97,08\% dan hanya $2,92 \%$ nasabah yang mengelola usahanya dengan melakukan kemitraan dengan pihak lain.

d) Berdasarkan status hukum usaha studi menemukan bahwa sebagian besar nasabah pembiayaan UMKM dari PT. BPRS Ampek Angkek Candung tidak memiliki izin usaha yaitu sebesar $68 \%$ dan sebesar $32 . \%$ responden memiliki izin usaha dalam menjalankan usahanya.

e) Dilihat dari jumlah modal awal yang dimiliki untuk memulai usaha, maka nasabah pembiayaan UMKM dari PT. BPRS Ampek Angkek Candung memiliki modal awal untuk memulai usaha dengan jumlah Rp1.000.000,0 Rp5.000.000,00. yaitu sebesar 49,51\%. dan sebesar $17,48 \%$ nasabah memiliki modal awal antara Rp5.000.000,00 Rp10.000.000,00, dan yang memiliki modal awal lebih besar dari Rp15.000.000,00 yaitu sebesar $6.80 \%$

f) Dari jumlah tenaga kerja yang dipekerjakan ditemukan bahwa sebagian besar nasabah pembiayaan UMKM dari PT. BPRS Ampek Angkek Candung mempunyai tenaga kerja $1-5$ orang dalam menjalankan usahanya, yakni sebesar $87,38 \%$, sedangkan $\quad 9,70 \%$ mempekerjakan $6-10$ orang tenaga kerja dalam menjalankan usahanya, dan yang memiliki tenaga kerja lebih dari 10 orang yaitu adalah sebesar 2,92\%.

Karakteristik pembiayaan yang diberikan oleh PT. BPRS Ampek Angkek Candung terhadap nasabah UMKM didasarkan pada jenis, jumlah dan jangka waktu pembiayaan produktif yang diberikan, dengan hasil analisis sebagai berikut:

a) $91,26 \%$ nasabah menerima pembiayaan modal kerja, sedangkan sebanyak $8,74 \%$ nasabah menerima pembiayaan investasi.

b) Jumlah pembiayaan UMKM adalah berkisar antara Rp5.000.000,00 Rp10.000.000,00 diberikan kepada 42,72\% nasabah. Sedangkan, jumlah pembiayaan lebih besar dari Rp20.000.000,00 
diberikan kepada 24,26\% nasabah. Jumlah pembiayaan antara Rp15.000.000,00 Rp20.000.000,00 sebanyak 5,83\% dari jumlah keseluruhan nasabah.

c) $97,08 \%$ jangka waktu pembiayaan yang diberikan adalah dengan jangka waktu $1-3$ tahun, dan sisanya $2,92 \%$ dengan jangka waktu lebih dari 3 tahun.

Hasil estimasi dari dengan menggunakan pendekatan ekonometrik khususnya metode regresi linier berganda dapat dilihat pada tabel di bawah ini.

Tabel 4. Hasil Estimasi Studi

\begin{tabular}{|c|c|c|c|c|c|c|c|}
\hline \multirow[b]{2}{*}{ Model } & \multicolumn{2}{|c|}{ Unstandardized Coefficients } & \multirow{2}{*}{$\begin{array}{c}\begin{array}{c}\text { Standardized } \\
\text { Coefficients }\end{array} \\
\text { Beta }\end{array}$} & \multirow[b]{2}{*}{$\mathrm{t}$} & \multirow[b]{2}{*}{ Sig. } & \multicolumn{2}{|c|}{ Collinearity Statistics } \\
\hline & $\mathrm{B}$ & Std. Error & & & & Tolerance & VIF \\
\hline (Constant) & 7.540E7 & $1.968 \mathrm{E} 7$ & & 3.832 & .000 & & \\
\hline $\begin{array}{l}\text { pembiayaan } \\
\text { produktif }\end{array}$ & 5.344 & 1.904 & .775 & 2.807 & .006 & .065 & 15.364 \\
\hline asset usaha & .546 & .267 & .350 & 2.044 & .044 & .169 & 5.921 \\
\hline tenaga kerja & $-2.354 \mathrm{E} 7$ & $9.401 \mathrm{E} 6$ & -.472 & -2.504 & .014 & .140 & 7.158 \\
\hline $\mathbf{R}$ & & & & & & & $\mathbf{0 , 7 1 3}$ \\
\hline $\mathbf{R}^{2}$ & & & & & & & 0,509 \\
\hline F test & & & & & & & 34,160 \\
\hline
\end{tabular}

Sumber: Pengolahan data lapangan.

Dari hasil estimasi di atas tampak bahwa ketiga variabel independen mempunyai nilai sig. Lenih kecil dari 0,050. Hal ini berarti bahwa semua variabel independen berpengaruh signifikan terhadap variabel dependen. Persamaan structural dari hasil estimasi tersebut adalah;

$\mathrm{Y}=7,540+5,344 \mathrm{PP}+0,546 \mathrm{~A}-2,354 \mathrm{~L}$

$$
(3,832)(2,807) \quad(2,044) \quad(-2,504)
$$

Hasil estimasi ini menunjukkan bahwa pembiayaan produktif yang diberikan oleh PT. BPRS Ampek Angkek Candung kepada nasabah pembiayaan Usaha Mikro Kecil Menengah (PP), berpengaruh signifikan dan positif terhadap nilai produksi UMKM (Y). Hal ini ditunjukkan dengan nilai koefisien regresi sebesar 5,344 dan nilai t-test sebesar 2,807 nilai ini lebih besar daripada nilai t-tabel $(1,980)$. Nilai koefisien regresi sebesar 5,344 berarti bahwa dengan asumsi cateris paribus, jika terjadi peningkatan pembiayaan produktif sebesar 1 unit satuan (rupiah), maka akan meningkatkan nilai produksi usaha sebesar 5,344 unit satuan (rupiah).

Besarnya aset usaha (A) yang dimiliki oleh nasabah pembiayaan UMKM berpengaruh positif dan signifikan terhadap nilai produksi usaha (Y). Hal ini ditunjukkan oleh nilai koefisien regresi sebesar 0,546, dan nilai t-test sebesar 2,044. Jika terjadi peningkatan aset usaha sebesar 1 unit satuan (rupiah), maka akan meningkatkan nilai produksi usaha sebesar 0,546 unit satuan (rupiah), dengan asumsi cateris paribus. Hal ini berari bahwa dengan semakin meningkatnya aset usaha yang dimiliki oleh nasabah pembiayaan UMKM, maka akan semakin meningkat pula nilai produksi usahanya.

Jumlah tenaga kerja (L) yang bekerja pada nasabah pembiayaan UMKM berpengaruh signifikan dan negatif terhadap nilai produksi usaha $(\mathrm{Y})$. Hal ini ditunjukkan oleh nilai koefisien regresi sebesar -2,354, dan tanda negatif yang berarti bahwa banyaknya tenaga kerja 
berpengaruh negatif terhadap nilai produksi usaha. Jika terjadi peningkatan atau penambahan jumlah tenaga kerja yang dipekerjakan oleh nasabah pembiayaan UMKM sebanyak 1 unit satuan (orang), maka akan menurunkan nilai produksi usaha mereka sebesar 2,354 satuan (rupiah). Dengan kata lain, semakin banyaknya tenaga kerja akan semakin menurunkan nilai produksi usaha. Hal ini dikarenakan usaha berskala mikro, kecil dan menengah sehingga kapasitas produksi sangat terbatas. Penambahan tenaga kerja seringkali menjadi beban dalam usaha karena keterbatasan dalam peningkatan skala usaha.

Dari hasil estimasi ini dapat dilihat bahwa hasil penelitian ini sejalan dengan penelitian terdahulu yang dilakukan oleh Herry dkk (2006), serta Malik dan Siringongingo (2007) yang mengemukakan bahwa perkuatan permodalan usaha mikro kecil menengah yang diberikan oleh pihak perbankan dan jumlah aset usaha berpengaruh signifikan dan positif terhadap nilai produksi usaha UMKM. Namun, yang membedakan dengan hasil penelitian sebelumnya adalah pada penelitian ini tenaga kerja berpengaruh signifikan dan negatif terhadap nilai produksi usaha mikro kecil menengah.

Selanjutnya, dari hasil estimasi ditemukan nilai koefisien determinasi $\left(\mathrm{R}^{2}\right)$ sebesar 0,509. Hal ini berarti perubahan secara rata-rata variabel besarnya pembiayaan produktif yang diberikan oleh PT. BPRS Ampek Angkek Candung kepada nasabah pembiayaan UMKM (K), variabel besarnya aset usaha yang dimiliki oleh nasabah pembiayaan (A), dan banyaknya tenaga kerja yang dipekerjakan (L) secara bersama-sama mempengaruhi nilai produksi usaha sebesar 50,9\%. Sedangkan, sebanyak 49,1\% dipengaruhi oleh variabel lainnya yang tidak diikutsertakan dalam penelitian.

Dari hasil uji $\mathrm{F}$ diperoleh nilai $\mathrm{F}$ test sebesar 34,160 dengan nilai signifikansi sebesar 0,000 . Nilai ini lebih besar dari pada nilai F-tabel $(2,68)$, hal ini berarti bahwa variabel besarnya pembiayaan produktif $(\mathrm{K})$, variabel aset usaha (A), dan variabel tenaga kerja (L) secara bersama-sama mempengaruhi variabel nilai produksi usaha (Y).

Dari hasil penelitian dapat dirumuskan implikasi kebijakan yang perlu dilakukan oleh pihak perbankan, pemerintah dan pelaku usaha dalam upaya pengembangan usaha mikro kecil menengah (UMKM), sebagai berikut:

1. Meningkatkan pembiayaan produktif terhadap Usaha Mikro Kecil Menengah (UMKM), dengan kerjasama antara Pemerintah daerah dan pihak perbankan untuk menyalurkan pembiayaan produktif untuk UMKM.

2. Pihak perbankan sebagai penyalur pembiayaan produktif untuk UMKM diharapkan dapat memberikan keringanan, dan kemudahan dalam proses pembiayaan tersebut. Prosedur yang mudah, tingkat margin yang rendah, dan pelayanan yang baik dari pihak perbankan akan meningkatkan akses pelaku usaha UMKM ke pembiayaan perbankan

3. Perlu adanya peningkatan peranan Bank Pembiayaan Rakyat Syariah dalam mengembangkan usaha rakyat. Kehadiran Bank Pembiayaan Rakyat Sayariah khususnya di daerah-daerah pedesaan akan sangat membantu masyarakat dalam mengembangkan usaha mereka.

4. Diperlukan peningkatan pendidikan dan keterampilan terhadap tenaga kerja agar dapat meningkatkan kualitas tenaga kerja, sehingga dapat menghasilkan produksi yang lebih banyak dan mempunyai kualitas yang tinggi.

\section{3) Alternative Sumber Pembiayaan Mikro di Sumatera Barat}

Di Sumatera Barat saat ini terdapat 7 BPRS dari 109 BPR, disamping itu ada lembaga pembiayaan berskala mikro yang peroperasi di tengah masyarakat baik lembaga keuangan formal maupun non formal. Berikut akan dikemukakan berbagai alternative pembiayaan mikro formal di wilayah ini, 
a) Lembaga Keuangan Mikro Agribisnis (LKM-A); pendirian lembaga ini diprakarsai oleh Masril Koto pada tahun 2007, pemuda putus sekolah ini memiliki semangat untuk keluar dari lingkaran kemiskinan, tidak hanya bagi keluarganya tetapi juga masyarakat di desanya, Koto Tinggi Kecamatan Baso Kabupaten Agam . LKMA yang pertama didirikannya bernama LKMA Prima Tani, lembaga pembiayaan yang tumbuh dari semangat kebersamaan untuk maju bersama dalam wadah koperasi, lembaga ini sangat berperan sebagai sumber pembiayaan bagi petani untuk mengembangkan usaha produktif.

Pada saat pendiriannya LKMA memili modal sebesar Rp 15.000.000 dari penjualan saham yang berharga $\mathrm{Rp}$ 100.000,- dan pada saat ini telah memiliki asset senilai Rp 250 Milyar degan lebih dari 500 unit dan menyerap tenaga kerja lebih dari 1.500 orang anak keluarga petani di seluruh wilayah Sumatera Barat. Berbagai penghargaan juga telah diraih seperti "danamon Award" dan "Indonesia Berpresatsi Award". Kesuksesan ini tentunya tidak diraih dengan mudah, banyak tantangan dan hambatan yang telah berhasil dilewati, kesuksesan ini juga tidak terlepas dari peran berbagai lembaga pendukung, diantaranya AFTA merupakan yayasan yang didirkan oleh Alumni Fakultas Pertanian Universitas Andalas, peran para pemuka adat dan masyarakat juga tidak dapat diabaikan begitu saja. Bahkan mesjid menjadi media penting untuk membicarakan berbagai permaslahan dalam bisnis lembaga ini.

b) Kredit Mikro Nagari (KMN): merupakan pembiayaan yang bersumber dari dana APBD Propinsi Sumatera Barat pada periode 20072010, dana yang dialokasikan untuk setiap nagari adalah sebesar Rp 300.000,- dengan target penerima adalah Rumah Tangga Miskin (RTM), dimana tujuan penyaluran KMN adalah untuk memberikan stimulasi tambahan modal usaha bagi keluarga miskin baik secara berkelompok maupun individual di tingkat nagari agar mereka mampu mengembangkan usaha mereka menjadi usaha yang mandiri dan berkelanjutan, dimana jumlah nagari dan kelurahan di Sumatera Barat adalah \pm 800. Namun Program ini terhenti pada tahun 2011 karena banyak dana pembiayaan yang macet. Hal ini disebabkan oleh lembaga yang mengelola di nagari kurang berkompeten dalam mengelola dana. Dari 19 kota kabupaten, yang membentuk lembaga khusus untuk mengelola dana ini hanya kabupaten Agam dengan mendirikan BMT Madani yang berbasis masjid di setiap nagari di wilayah ini. Di daerah lainnya KMN dikelola oleh POKJA (Kelompok Kerja) yang dibentuk oleh Nagari dengan tenaga pengelola berasal dari masyarakat nagari yang pada umumnya belum berpengalaman mengelola lembaga keuangan. Akibatnya program ini belum dapat berfungsi sebagaimana yang diharapkan.

c) BMT (Baitul Maal Wat Tamwil) KJKS (Koperasi Jasa Keuangan Syariah); Sejarah keberadaan BMT di Indonesia tidak terlepas dari dibentuknya Yayasan Inkubasi Bisnis Usaha Kecil (YINBUK). Yayasan ini dibentuk sekitar bulan Maret tahun 1995 melalui prakarsa dari Majelis Ulama Indonesia (MUI), Ikatan Cendikiawan Muslim Indonesia (ICMI) beserta Bank Muamalatyang merupakan bank pertama di Indonesia dengan prinsip syariah. Sedangkan untuk di Sumatera Barat, khususnya di kabupaten Agam dan Kota Padang lembaga ini merupakan lembaga yang dibentuk pasca penyaluran KMN.

Dari hasil evaluasi, program pengelolaan KMN/KMK yang 
dilakukan oleh lembaga pengelola ternyata kurang efektif, karena tenaga pengelola pada lembaga pengelola KMN tidak memiliki kompetensi yang memadai. Berkaca dari program tersebut yang mengalami kegagalan, maka Pemerintah Kota Padang pada tahun 2010 merealisasikan alokasi anggaran Kredit Mikro Kelurahan (KMK) melalui Koperasi Jasa Keuangan Syariah Baitul Maal Wat Tamwil (KJKS-BMT) Padang Amanah Sejahtera. Lembaga ini merupakan lembaga keuangan mikro yang beroperasi berdasarkan prinsip-prinsip syariah yang menyelenggarakan simpan pinjam dalam bentuk koperasi jasa keuangan syariah, yang memadukan kegiatan ekonomi dan sosial masyarakat.

Pada tahun 2010 tersebut Pemerintah Kota Padang merealisasikan anggaran KMK melalui KJKS BMT di 54 kelurahan, dengan masing-masing kelurahan memperoleh dana sebesar Rp 300.000.000,- dengan jumlah keseluruhan untuk 54 kelurahan sebesar Rp 16.200.000.000,-. Alokasi dana anggaran ini berasal dari APBD Provinsi Sumatera Barat dan Kota Padang. Hingga saat ini pemda kota masih berkomitmen untuk mendukung peran lembaga ini dalam mendorong UMKM dan masyarakat miskin di kota ini. Untuk itu pemerintah kota menempatkan dua orang tenaga pengelola yang terlatih dalam pengelolaan lembaga keuangan khususnya koperasi yang biaya gajinya dibayarkan oelh APBD kota Padang. Sejalan dengan itu, MES (Masyarakat Ekonomi Syariah) Provinsi Sumatera Barat juga mendorong pendirian satu desa satu BMT di wilayah Sumatera Barat dengan dukungan pelatihan bagi tenaga pengelola.

d) LPN (Lumbung Pitih Nagari); merupakan lembaga yang dibentuk dan tumbuh berkembang di tengah masyarakat local sejak zaman pemerintahan Belanda. Dan di era gubernur Azwar Annas, LPN ditata dan dibenahi menjadi lembaga formal di Nagari (bentuk pemerintahan terendah di Minang Kabau). Namun dengan aturan Deregulasi Perbankan maka LPN menjadi BPR, akan tetapi di era otonomi daerah setelah kembali ke konsep Nagari, maka LPN kembali tumbuh di dalam masyarakat Minang Kabau.

Model organisasi LPN pasca otonomi daerah ini meniru koperasi dimana masyarakat yang ingin menjadi anggota harus menyetorkan sejumlah dana untuk simpanan wajib. Manajemen LPN direkrut dari anggota masyarakat desa dengan pengendalian internal dilakukan oleh pengurus LPN. Pengurus desa tidak bertanggung jawab dalam pengawasan LPN. Sedangkan Supervisi dan pengawasan eksternal dilakukan oleh Pemerintah Propinsi dengan pendampingan dari Bank Pembangunan Daerah.

e) BAZNAS (Badan amil Zakat Nasional): adalah lembaga yang menghimpun dana zakat, infak dan sadaqah serta waqaf tunai dari masyarakat. Di kota Padang, penyaluran dana dilakukan melalui program yang disebut dengan DBU (Dana Bantuan Usaha). Merupakan dana yang disalurkan untuk usaha produktif dan dikembalikan tanpa imbalan (balas jasa) pada pengeolala dana alam hal ini BAZNAS kota Padang. Kajian yang dilakukan oleh Rezki (2014) memperlihatkan bahwa dana DBU ini lebih banyak disalurkan untuk usaha perdagangan karena perputarannya cepat dan pengembaliannya lancer.

Disamping lembaga keuangan formal di atas, terdapat berbagai bentuk dan pola pembiayaan non formal di Sumatera Barat yang dikelola secara individual oleh anggota masyarakat. Mulai dalam bentuk arisan (julo-julo) hingga dalam bentuk 
pinjaman harian, mingguan dan bulanan. Dimana nilai bunga atau balas jasa yang harus dibayar oleh peminjam sangat besar. Bentuk dan pola pembiayaan ini beragam sesuai dengan wilayah dan kondisi daerah dimana pembiayaan tersebut beroperasi. Di kawasan pesisir misalnya, pembiayaan dilakukan harian, diberikan pada saat melaut dan harus dikembalikan setelah hasil tangkpan terjual. Sedangkan di daerah pertanian diberikan pada saat tanam lalu harus dibayar pada saat panen. Sedangkan di daerah perdagangan lebih bervariasi bentuk dan jangka waktu pembiayaannya.

Dari uraian di atas, dapat dilihat bahwa berbagai bentuk dan sumber pembiayaan dari lembaga keuangan formal dan non formal di Sumatera Barat merupaan dinamika dan sekaligus tantangan bagi BPRS di wilayah ini. Meskipun jumlah BPRS di Sumatera Barat baru 7 Unit, tidakmenutup kemungkinan bagi BPRS yang ada ini untuk memperluas jangkauan layanan dengan menjadi lembaga keuangan mikro formal yang ada ditengah-tengah masyarakat sebagai mitra. Dan bahka tidak tertutup peluang untuk menggandeng para pelempar uang (pembiayaan non formal) sebagai mitra dengan memberikan pelatihan dan peningkatan pengawasan tentunya. Agar pola pembiayaan dan simpanan "bajapuik" yang selama ini telah dikenal masyarakat Sumatera Barat dapat terus ditumbu kembangkan di era ekonomi yang semakin terbuka dan kompetitif.

\section{PENUTUP}

\section{Kesimpulan}

Berdasarkan hasil studi dapat dibuat kesimpulan sebagai berikut:

1) Nasabah yang mendapatkan pembiayaan produktif adalah berjenis kelamin laki-laki dengan tingkat umur yang berkisar antara 41 - 50 tahun., mayoritas nasabah telah menikah, dan berpendidikan SLTA, dengan pengalaman mengelola usaha antara 1 sampai 5 tahun.
2) Berdasarkan karakteristik usaha, pada umumnya nasabah pembiayaan BPRS mempunyai usaha di bidang perdagangan, usaha milik sendiri dengan tempat usaha yang juga milik sendiri dimana mayoritas responden dalam menjalankan usahanya tidak memiliki izin usaha resmi.

3) Berdasarkan karakteristik aset usaha, pada umumnya nasabah pembiayaan memiliki modal awal dalam memulai usahanya adalah sebesar Rp1.000.000,00 - Rp5.000.000,00.

4) Berdasarkan jumlah tenaga kerja yang dipekerjakan pada umumnya memiliki tenaga kerja dengan jumlah 1-5 orang.

5) Berdasarkan karakteristik pembiayaan produktif yang diberikan mayoritas pembiayaan produktif yang diberikan adalah pembiayaan modal kerja, berkisar antara Rp5.000.000,00 Rp10.000.000,00, dan jangka waktu pembiayaan yang diberikan pada umumnya adalah antara $1-3$ tahun.

6) Besarnya pembiayaan produktif $(\mathrm{K})$, aset usaha yang dimiliki UMKM (A), dan jumlah tenaga kerja (L) mempengaruhi nilai produksi usaha UMKM (Y) secara signifikan.

7) Pembiayaan produktif dan aset usaha berpengaruh signifikan dan positif terhadap nilai produksi usaha. Sedangkan, banyaknya tenaga kerja berpengaruh signifikan dan negatif terhadap nilai produksi usaha.

8) Lembaga pembiayaan alternative di Sumatera Barat dapat dijadikan mitra oleh BPRS Sumatera Barat agar jangkauan layanan dapat diperluas dalam rangka mendukung terwujudnya "financial inclusive".

\section{Rekomendasi}

Diperlukan kerjasama antara pemerintah daerah dan lembaga keuangan untuk mengembangkan pembiayaan bagi Usaha Mikro Kecil Menengah UMKM di Sumatera Barat, khususnya Kabupaten Agam. Hal ini dapat dilakukan dengan pemberian bantuan permodalan dan pengembangan usaha secara terusmenerus. 
Hasil studi ini menunjukkan bahwa tenaga kerja berpengaruh negatif terhadap nilai produksi usaha UMKM, untuk itu diperlukan dukungan dan bantuan dari pemerintah daerah, dan lembaga pendidikan untuk mengadakan program pendidikan dan pelatihan dalam upaya meningkatkan kualitas dan produktifitas tenaga kerja.

Pelaku usaha juga harus berusaha mengelola usaha dengan lebih profesional dan memenuhi aspek legalitas usaha agar memudahkan bagi pihak pemerintah maupun lembaga keuangan untuk melakukan berbagai usaha pemberdayaan dan bantuan permodalan

Sampai tahun 2012, baru terdapat 7 BPRS untuk wilayah Sumatera Barat yang terdiri dari 7 kota dan 12 Kabupaten, untuk itu perlu didorong pertambahan BPRS agar layanan perbankan syariah dapat menjangkau masyarakat Sumatera Barat yang mayoritas adalah penduduk beragama Islam, demikian juga dengan jangkauan layanan untuk UMKM di wilayah ini. Disamping itu BPRS juga bisa bermitra dengan lembaga keuangan mikro formal yang ada di daerah ini.

\section{DAFTAR PUSTAKA}

\section{$\underline{10.22202 / e c o n o m i c a .2014 . v 3 . i 1.231}$}

Adrimas. 1993. Ekonomi Pembangunan. Yogyakarta: Pusat Antar Universitas (PAU) Studi Ekonomi Universitas Gadjah Mada.

Agung. I Gusti, Pasay. Haidy, dan Suguharso. 1994. Teori Ekonomi Mikro Suatu Analisis Produksi Terapan. Jakarta: Lembaga Penerbit Fakultas Ekonomi Universitas Indonesia.

Antonio, Muhammad Safi'i. 1999. Bank Syariah bagi Bankir dan Praktisi Keuangan. Jakarta: Tazkia Institute.

Antonio, Muhammad Safi'i. 2001. Bank Syariah: Dari Teori ke Praktik. Jakarta: Gema Insani.

Artika, Ida Bgs Eka, Peranan Bank Perkreditan Rakyat ( BPR ) Dalam
Menggerakkan Kegiatan Usaha Mikro, Kecil Dan Menengah Di Nusa Tenggara Barat, Media Informasi Ilmiah Universitas Islam Al-Azhar, AVESINA, Vol 2 Nomor 2, Desember 2010, ISSN : $2086-8960$

Azriani, Z, Harianto \& Nunung Nuryatono, 2008, Peranan Bank Perkreditan Rakyat Terhadap Kinerja Usaha Kecil di Sumatera Barat, Forum Pascasarjana Vol. 31 No. 3 Juli 2008: 173-188, IPB Bogor.

Badan Pusat Statistik Indonesia. 2009. Survei Industri Mikro dan Kecil 2009.

Badan Pusat Statistik Sumatera Barat. 2010. Sumatera Barat dalam Angka Tahun 2010.

Bank Indonesia .2010. Statistik Perbankan Syariah Indonesia 2010. -2014, Statistik Perbankan Syariah Indonesia 2014.

Baskara, I Gde Kajeng, 2013, Lembaga Keuangan Mikro Di Indonesia, jurnal Buletin Studi Ekonomi, Vol. 18, No. 2, Agustus 2013, FEB Universitas Udayana, Denpasar-Bali.

Case. K, Fair.R. 2003. Prinsip-Prinsip Ekonomi Mikro, Edisi Ketujuh. Indonesia: PT. Indeks Kelompok Gramedia.

Dernburg.Thomas, Dougall.Duncan. 1982. Ekonomi Makro Perhitungan, Analisis, dan Kebijaksanaan Perekonomian. Jakarta Pusat: Erlangga.

Ekonomi Neraca 2010. Dampak Ekonomi Gempa Sumatera Barat. Diakses pada tanggal 11 November 2010.

Firdaus, Muhammad. 2004. Ekonometrika Suatu Pendekatan Aplikatif. Jakarta : Bumi Aksara.

Gandhiar, Nova, 2013. Peran Kredit BPR Bank Pasar Pada Perkembangan UMKM Di Kota Pontianak, Jurnal Curvanomic, Vol 2, No 2. Pontianak.

Ghozali, Imam. 2005. Aplikasi Analisis Multivariate Dengan Program SPSS. Semarang: Badan Penerbit Universitas Diponegoro.

Gujarati, Damodar. 2005. Ekonomertika Dasar. Jakarta : Erlangga.

Gusman, Hadi. 2010. Persepsi Mahasiswa Ekonomi terhadap Perbankan Syariah 
(Studi Kasus pada Fakultas Ekonomi

Universitas Andalas). Skripsi:

Universitas Andalas, Padang.

Hamdan, Wijaya. 2006. Analisis

Komparatif Resiko Keuangan Bank

Perkreditan Rakyat (BPR)

Konvensional dan BPR Syariah. Jurnal Manajemen dan Bisnis Sriwijaya Vol. 4

No. 7 Juni 2006. Diakses pada tanggal 7

Oktober 2010.

Herry dkk. 2006. Studi Peningkatan Peran

Bank Perkreditan Rakyat (BPR) dalam

Pembiayaan Usaha Mikro Kecil (UMK)

di Sumatera Barat. Jurnal Penelitian

kerjasama antara Bank Indonesia dan

Centre for Banking Research

Universitas Andalas. Diakses pada

tanggal 20 Desember 2010.

2009, Kajian Pelaksanaan

Penyaluran KMN di Sumatera Barat,

BAPPEDA Sumatera Barat.

Husein, Umar. 1996. Metode Penelitian

untuk Skripsi dan Tesis Bisnis.

Yogyakarta: Liberty.

Kementrian Negara Koperasi dan Usaha

Kecil \& Menengah. 2008. Statistik

Usaha Mikro Kecil Menengah tahun 2007-2008.

Laudin, Afriadi. 2010. Kebijakan Pengembangan Industri Sumatera Barat. Bukittinggi: Workshop Pengembangan Industri Elektronika di Luar Pulau Jawa dan Batam.

Lembaga Pengkajian Koperasi dan UKM. 2006. Kajian Dampak Program Perkreditan dan Perkuatan permodalan Usaha Kecil Menengah terhadap Perekonomian Daerah. Jurnal Pengkajian Koperasi dan UKM No. 1 tahun 2006. Diakses pada tanggal 25 Desember 2010.

Malik, Rachmawati dan Siringongingo, Hotniar. 2007. Analisis Pengaruh Kredit, Aset, dan Jumlah Pegawai terhadap Pendapatan Usaha Kecil Menengah (UKM) Penenrima Kredit Bank Perkreditan Rakyat. Jurnal Ekonomi Universitas Gunadarma.

Malik, Tajuddin. 2008. Pengaruh Pemberian Kredit Kepada Sektor Usaha Mikro, Kecil, Dan Menengah Terhadap Kinerja Keuangan Perbankan Di
Sulawesi Selatan. Jurnal STIE LPI, September 2008 Vol. 5 N0.2: 65-75. Diakses pada 7 Oktober 2010.

Mankiw, Gregory. 2003. Teori Makro Ekonomi. Jakarta: Erlangga.

Nachrowi, Djalal dkk. 2005. Penggunaan Teknik Ekonometri. Jakarta : PT. Raja Grafindo Persada.

Nicholson, Walter. 2002. Mikro Ekonomi Intermediate dan Aplikasinya, Edisi Kedelapan. Jakarta: Erlangga.

Ocky, Farah Margaretha. 2007. Pengaruh Bank Relationship terhadap Profitabilitas Perusahaan di Indonesia. Jurnal Bisnis dan Akuntansi Vol. 3 No.3 Desember 2007: 237-252. Diakses pada tanggal 12 Januari 2011.

Pusat Pengkajian dan Pengembangan Ekonomi Islam (P3EI). 2008. Ekonomi Islam. Jakarta: Rajawali.

PT. BPRS Ampek Angkek Candung. 2011. Laporan Keuangan 2008-2009.

Safitri, Fera. 2009. Analisis Peranan Pembiayaan Mikro oleh BMT Agam Madani Terhadap Pendapatan Pengusaha Industri Kecil di Kabupaten Agam. Skripsi: Universitas Andalas. Padang.

Samuelson, Nordhaus. 2004. Ilmu Makro Ekonomi, Edisi Tujuh Belas. Jakarta: PT. Media Global Edukasi.

Sari, Zurnelia, 2013, Analisis Kinerja Program Penanggulangan Kemiskinan Melalui KJKS BMT (Studi Pada Kota Padang, UNP, Padang,

Singarimbun. M, Effendi. S. 1989. Metode Penelitian Survai. Jakarta: LP3ES. Statistik Indonesia. 2009.

Sugianto, Catur. 1994. Ekonometrika Terapan, Edisi Pertama. Yogyakarta: BPFE.

Sumitro, Warkum. 1996. Asas-asas Perbankan Islam dan Lembagalembaga Terkait (Bamui dan Takaful) di Indonesia. Jakarta: PT. Raja Grafindo Persada.

Survei Industri Mikro dan Kecil. 2010. Industri Mikro dan Kecil Indonesia tahun 2010. 
Todaro, Michael P. 1998. Pembangunan

Ekonomi di Dunia Ketiga Edisi

Keenam. Jakarta: Erlangga.

Walpole, E. Ronald. 1995. Pengantar Statistika. Jakarta: PT. Gramedia Pustaka Utama.

Zahro, Binti Inazatuz, 2010, Peranan Lembaga Keuangan Mikro Syariah (Lkms) Serta Pengaruhnya Terhadap Usaha Mikro,Kecil Dan Menengah (Umkm)Sebagai Penggerak Perekonomian Di Indonesia, FEB Universitas Airlangga, Surabaya.

Zain, Yunus.dkk. 2007. Skema Pembiayaan Perbankan Daerah Menurut Karakteristik UMKM pada Sektor Ekonomi Unggulan di Sulawesi Selatan. Jurnal penelitian Universitas Hasanuddin. Makassar. 